\title{
Alterations in Some Hematological and Biochemical Parameters in Egyptian Buffaloes Suffering from Traumatic Reticuloperitonitis and Its Sequelae
}

\author{
Ahmed N F NEAMAT-ALLAH \\ Department of Clinical Pathology, Faculty of Veterinary Medicine, Zagazig University, 1 Alzeraa Street \\ Postal Code 44511, Zagazig City, Sharkia Province, Egypt \\ Corresponding author: drnemovete@yahoo.com
}

Bulletin UASVM Veterinary Medicine 72(1) / 2015,

Print ISSN 1843-5270; Electronic ISSN 1843-5378

DOI:10.15835/buasvmcn-vm: 11021

\begin{abstract}
Thirty four buffaloes were introduced to Veterinary Clinic at the Faculty of Veterinary Medicine suffered from anorexia. Clinical examination revealed stiffness in gait with positive pain reactions. By using ultrasonographic examinations, buffaloes were classified into two groups. The first group was recognized as traumatic reticuloperitonitis (TRP) while the second group was recognized as traumatic pericarditis (TP) while another ten buffaloes used as healthy control. Hematological studies revealed non significant change in erythogram. Granulocytic leucocytosis, lymphopenia, monocytosis and thrombocytosis in both traumatic groups. Biochemical studies revealed hyperglobulinemia, hypoalbuminemia, hyperfibrinogenemia in both traumatic groups. While an increase of cardiac troponin I(cTnI), blood urea nitrogen and activities of alanine and aspartate aminotransferase (ALT \&AST) in TP buffaloes with increase in heart rate, distension of the jugular vein and brisket oedema. Without alteration in creatinine level in all groups. So it is concluded that estimation of cTnI could be aid for diagnosis of traumatic pericarditis in buffaloes.
\end{abstract}

Keywords: Blood chemistry, Buffaloes, Cardiac makers, Hematology, Pericarditis, Troponin I.

\section{INTRODUCTION}

Buffaloes have economical importance in milk and meat production in the valley of the River Nile in Egypt (GOVS, 2005). There are many causes in which myocardial damage happens in animals as infectious diseases, toxic chemicals, nutritional deficiencies or trauma etc., Yearly we lose a lot of money and time due to missed diagnoses of heart diseases or problems. There are some external tools and some traditional cardiac markers for routine diagnosis of heart diseases, but all of these have some limitations as they do not possess specificity and sensitivity to heart (Undhad et al., 2012).

Troponin is a complex of regulatory proteins that are integral to contraction of cardiac muscle, but not smooth muscle. Troponin is not found in other tissues (Winder and Walsh, 1990). Cardiac troponin I (cTnI) is uniquely expressed in the myocardial and has been widely recognized as highly sensitive and specific serum markers for diagnosis of non-invasive myocardial necrosis (Zethelius and Johnston, 2006).

The most common sequelae of TRP are TP (Watts and Tulley, 2013) which mean an inflammation of the pericardium with accumulation of inflammatory exudates. In bovine, it is always attributable to long sharp foreign bodies that penetrate reticulum, diaphragm then pericardium (Braun 2009). This perforation in the wall of the reticulum allows leakage of rumen contents, which contaminates the peritoneal cavity develops a localized peritonitis and frequently results in adhesions and less commonly 
develops diffuse peritonitis. Early diagnosis of TP is more difficult in buffaloes than in cattle (Saleh et al., 2008 and Mohamed, 2010) despite using of ultrasonographic examination remain a confirmatory tool for diagnosis of diseases of the digestive tract, but, it still not available for most veterinarians as much expensive and need for more experience and training. Therefore, the aim of this work is to diagnose of TP as a common sequelae of TRP in buffaloes by simple and inexpensive tests include hematological and biochemical markers.

\section{MATERIAL AND METHODS}

\section{Buffaloes}

Thirty four water buffaloes (Bubalus bubalis L.) 3-5 years old were introduced to the Veterinary Clinic at the Faculty of Veterinary Medicine, Zagazig University, Egypt .The animals were clinically diagnosed as traumatic using pain test reaction (Dirksen et al., 1990) and confirmed by ultrasonogarphic examinations of the reticulum, rumen and heart (Braun and Goetz, 1994 and Braun et al., 2001) that classified them into two groups. The first group was TRP (17 buffaloes). The second group was TP (17 buffaloes); another ten buffaloes were used as a normal (apparently healthy group). All buffaloes were feds on wheat hay, Trifolium alexandrinum and concentrate.

\section{Blood sampling}

Blood was collected from all animals by puncture of the jugular vein into three samples. The 1st blood samples were drown into EDTA tubes for hematological analysis. A 2nd blood samples were drown without anticoagulant in a sterile test tube for separation of serum then frozen for clinical chemistry analysis. A 3rd blood samples were drown on sodium citrate for fibrinogen estimation.

\section{Hematological examination}

The Complete Blood Count was evaluated in an automatic cell counter (Hospitex Hemascreen 18, Italy).

\section{Biochemical examination}

The serum total protein and serum albumin levels were measured (Doumas et al., 1981 and Drupt, 1974). The serum globulin level was calculated (Coles, 1986) and serum activities of alanine and aspartate aminotransferase (ALT \& AST) were determined (Reitman and Frankel, 1957). While fibrinogen concentration was estimated in citrated plasma (Benjamin, 1979), cardiac troponin I (cTnI) was estimated (Collinson and Boa, 2001) using commercial kits. Serum creatinine level was estimated (Husdan and Rapoport, 1968) while blood urea nitrogen was estimated (Putton and Crouch, 1977)

\section{Statistical analysis}

Data obtained from this investigation were statistically analysed using the one way analysis of variance (ANOVA) using SPSS 16.0 for windows (Tamhane and Dunlop, 2000). Means at the same column followed by different letters were significantly different and the highest value was represented with the letter (a). Significant difference at $p \leq 0.01$

\section{RESULTS AND DISCUSSION}

Traumatic reticuloperitonitis (TRP) or hardware disease is a relatively common disease in adult bovine due to using of their tongue without differentiate between feed and metallic objects in feedstuffs (Divers and Peek, 2007) .The risk of TRP and sequelae is considerably higher in buffaloes than in cattle (Misk et al., 2001). TRP were caused by the ingestion of a sharp foreign body, such as a piece of wire or a nail in the reticulum, in the presence of predisposing factors such as pregnancy and parturition (Rebhun et al., 1995), resulting migration of it into the reticular wall which is anatomically besides the heart and peritoneum (Divers and Peek 2007). Peritonitis, reticular abscess, thoracic abscess and traumatic pericarditis (TP) were detected as sequelae of TRP (Abd El-Aal, 2009 and Hajighahramani and Ghane, 2010).

Regarding the results of hematological studies (Tab. 1) revealed insignificant change in erythrogram. While granulocytic leucocytosis and thrombocytosis as a common finding of inflammation (Douglas and Wardrop, 2010), granulocytosis, lymphopeina may be as a result of stress reaction to inflammation (Douglas and Wardrop, 2010) in the both traumatic groups. Monocytosis could be due to chronic inflammation (Coles, 1986)

Clinical symptoms of the both affected buffaloe groups include anorexia. In addition, there were a positive reactions during pain test including stiffness in gait, lordosis and painful during defecation and urination, which are common signs of TRP (Radostits et al., 2000). Increase heart rate (Tab. 2) in TP that may be due to pressure on the heart as a result of fibrinous changes in the 
pericardial sac (Braun, 2009). Ultrasonographic examination (Fig.1) revealed presence of a large network represent fibrin, fibrinous exudates and fluid in pericardial sac in the TP, which affecting basic cardiac function (Danjuma et al., 2014). Distension of the jugular vein, oedema in brisket and move towards of the umbilical region in case of TP (Fig.2), which could be attributed to congestive heart failure (Kahn and Line 2010). TRP showed half moon shape of the reticulum with a deposit on it's surface representing fibrin between reticulum and abdominal wall (Fig.3). These results explain the elevation in (cTnI) in the TP buffaloes that have been widely recognized as highly sensitive and specific serum markers for increased myocardial necrosis (Zethelius and Johnston, 2006). ALT revealed an increase in the TP group only that indicating hepatic congestion leads to degenerative change in liver, but not primary to liver disease (Braun, 2009). AST was increased in both groups which may be due to involvement of liver and or myocardial muscle (Kaneko et al., 2008). Prerenal azotemia i.e. increase of blood urea nitrogen in TP group could be caused by a decrease in blood flow to the kidneys due to congestive heart failure (Kumar et al., 2005). However, normal creatinine level in all groups confirms that there is no inherent kidney disease (Coles, 1986).

Analysis of blood serum and plasma proteins (Tab. 3) revealed alteration which may follow tissue destruction and inflammation (Gruys et al., 1994) and or anorexia due to indigestion (Abd El-Aal et al., 2009). Hypoalbuminemia in TRP and TP could be attributed to the production of protein in the liver during inflammation is switched towards increased synthesis of positive acute phase proteins (APPs.) with a concomitant decrease in the synthesis of albumin. APPs play a major role to prevent inflammation, and contribute to healing (Cray et al., 2009). The decreased albumin level also suggested a selective loss of albumin or sequestration of albumin into body spaces (Coles, 1986) which were seen as oedema in brisket and move towards of the umbilical region. Despite a hypoalbuminaemia, the total serum protein concentrations increased as a result of hyperglobulinaemia (Saleh et al., 2008) .Hyperproteinaemia was also reported as a differentiating tool for TRP from other gastrointestinal diseases in cattle (Jafarzadeh et al., 2004). Hyperfibrinogenemia may be due to fibrinogen elevation in patients with gastrointestinal abnormalities (Memeh et al., 1992).

\section{CONCLUSIONS}

Buffaloes with TRP and TP revealed inflammatory markers manifested by granulocytic leucocytosis, thrombocytosis hyperfibrinogenemia etc., cTnI, AST and azotemia were increased in TP only. But, AST and azotemia can occurs in other

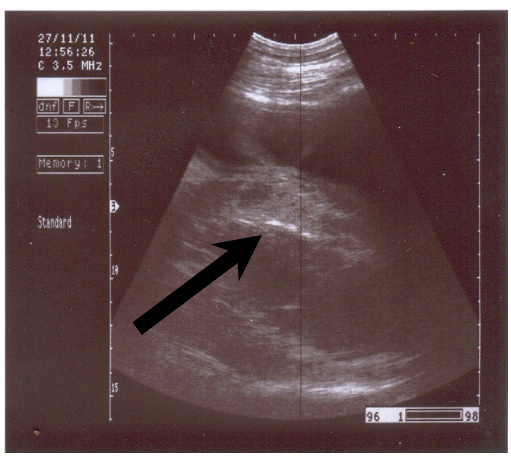

Fig.1. Ultrasonographic picture of TP group showed large network represent fibrin in the pericardium, 3.5 MHz sector probe.

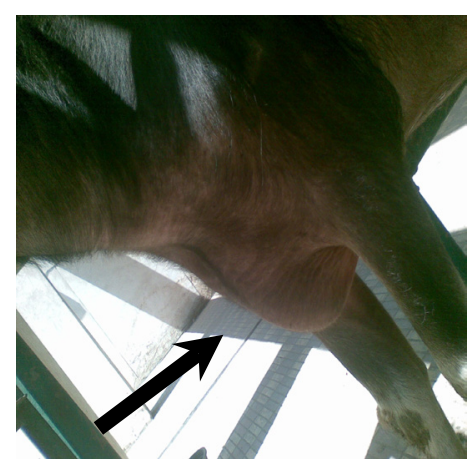

Fig.2. Buffaloe suffered from TP showed oedema in brisket

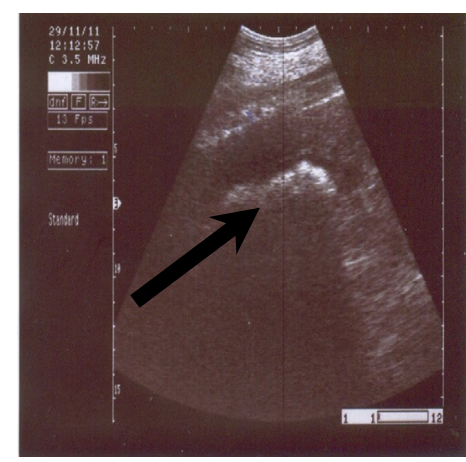

Fig.3. Ultrasonographic picture of TRP group showed half moon shape of the reticulum with a deposit on it's surface representing fibrin between reticulum and abdominal wall,3.5 MHz sector probe. 
Tab. 1. Alteration in some hematological parameters in buffaloes suffering from Traumatic reticuloperitonitis and its sequelae (mean values \pm SE)

\begin{tabular}{|c|c|c|c|c|c|c|c|c|}
\hline \multicolumn{9}{|c|}{ Parameters } \\
\hline Groups & $\begin{array}{c}\text { TLC } \\
\times 10^{3} / \mu \mathrm{l}\end{array}$ & $\begin{array}{c}\text { LYM } \\
\times 10^{3} / \mu \mathrm{l}\end{array}$ & $\begin{array}{c}\text { GRA } \\
\times 10^{3} / \mu\end{array}$ & $\begin{array}{c}\text { MID } \\
\times 10^{3} / \mu \mathrm{l}\end{array}$ & $\begin{array}{l}\text { Plattlets } \\
\times 10^{3} / \mu \mathrm{l}\end{array}$ & $\begin{array}{l}\text { RBCs count } \\
\times 10^{6} / \mu \mathrm{l}\end{array}$ & $\begin{array}{c}\mathrm{Hb} \\
\mathrm{gm} \%\end{array}$ & $\begin{array}{l}\text { PCV } \\
\%\end{array}$ \\
\hline TRP & $\begin{array}{c}10.49 \\
\mathrm{a} \pm 0.14 \\
\end{array}$ & $3.78^{b} \pm 0.03$ & $\begin{array}{c}3.50^{\mathrm{a}} \pm \\
0.12 \\
\end{array}$ & $3.21^{a} \pm 0.12$ & $\begin{array}{c}419^{\mathrm{a}} \pm \\
5.78\end{array}$ & $\begin{array}{c}8.33^{\mathrm{a}} \pm \\
0.20\end{array}$ & $\begin{array}{l}13.55^{\mathrm{a}} \\
\pm 0.07 \\
\end{array}$ & $\begin{array}{c}41.41^{\mathrm{a}} \pm \\
0.34\end{array}$ \\
\hline $\mathrm{TP}$ & $\begin{array}{l}10.47^{a} \\
\pm 0.22 \\
\end{array}$ & $3.66^{b} \pm 0.06$ & $\begin{array}{c}3.50^{\mathrm{a}} \pm \\
0.15\end{array}$ & $3.31^{\mathrm{a}} \pm 0.17$ & $\begin{array}{c}415.4^{\mathrm{a}} \pm \\
5.12\end{array}$ & $\begin{array}{c}8.23^{\mathrm{a}} \pm \\
0.16\end{array}$ & $\begin{array}{l}13.63^{\mathrm{a}} \\
\pm 0.08 \\
\end{array}$ & $\begin{array}{c}41.87^{\mathrm{a}} \pm \\
0.35\end{array}$ \\
\hline $\begin{array}{l}\text { Healthy } \\
\text { buffaloes }\end{array}$ & $\begin{array}{c}8.41^{b_{ \pm}} \\
0.04\end{array}$ & $4.98^{\mathrm{a}} \pm 0.14$ & $\begin{array}{c}1.49^{\mathrm{b}} \pm \\
0.12^{-}\end{array}$ & $1.93^{b} \pm 0.02$ & $\begin{array}{l}338.2^{b} \\
\pm 9.36\end{array}$ & $\begin{array}{c}8.39^{\mathrm{a}} \pm \\
0.15\end{array}$ & $\begin{array}{l}13.59^{a} \\
\pm 0.06\end{array}$ & $\begin{array}{c}41.05^{\mathrm{a}} \pm \\
0.73\end{array}$ \\
\hline $\mathrm{F}$ test & $* *$ & $* *$ & $* *$ & $* *$ & $* *$ & N.S & N.S & N.S \\
\hline
\end{tabular}

** Highly significant difference at $p \leq 0.01$; N.S not significant; PCV packed cell volume; $\mathbf{R B C}$ total erythrocytic count; LYM

lymphocytes; TLC total leukocytic count; GRA neutrophil, eosinophil and basophil; MID monocytes and some eosinophil; TRP traumatic reticuloperitonitis; TP traumatic pericarditis; LSD least significant difference.

Means in the same column with different superscript letters are significantly different.

Tab. 2. Alteration in some biochemical parameters in buffaloes suffering from Traumatic reticuloperitonitis and its sequelae (mean values $\pm \mathrm{SE}$ )

\begin{tabular}{ccccccc}
\hline \multicolumn{7}{c}{ Parameters } \\
\hline Groups & $\begin{array}{c}\text { Heart rate } \\
\text { Sec. }\end{array}$ & $\begin{array}{c}\text { Troponin I } \\
((\mathrm{ng} / \mathrm{ml}))\end{array}$ & $\begin{array}{c}\text { AST } \\
(\text { Unit/l) }\end{array}$ & $\begin{array}{c}\text { ALT } \\
(\text { Unit/l) }\end{array}$ & $\begin{array}{c}\text { Creatinine } \\
(\mathrm{mg} / \mathrm{dl})\end{array}$ & $\begin{array}{c}\text { Urea } \\
(\mathrm{mg} / \mathrm{dl})\end{array}$ \\
\hline TRP & $78.8^{\mathrm{b}} \pm 0.86$ & $0.093^{\mathrm{b}} \pm 0.01$ & $29.5^{\mathrm{b}} \pm 0.24$ & $12.00^{\mathrm{b}} \pm 0.36$ & $0.54^{\mathrm{a}} \pm 0.02$ & $18.32^{\mathrm{b}} \pm 0.28$ \\
\hline TP & $112.6^{\mathrm{a}} \pm 5.61$ & $0.865^{\mathrm{a}} \pm 0.72$ & $39.3^{\mathrm{a}} \pm 0.37$ & $17.39^{\mathrm{a}} \pm 0.24$ & $0.59^{\mathrm{a}} \pm 0.03$ & $26.4^{\mathrm{a}} \pm 0.50$ \\
\hline $\begin{array}{c}\text { Healthy } \\
\text { buffaloes }\end{array}$ & $77.6^{\mathrm{b}} \pm 1.63$ & $0.089^{\mathrm{b}} \pm 0.01$ & $26.9^{\mathrm{c}} \pm 0.31$ & $11.59^{\mathrm{b}} \pm 0.50$ & $0.57^{\mathrm{a}} \pm 0.01$ & $17.9^{\mathrm{b}} \pm 0.87$ \\
\hline F test & $* *$ & $* *$ & $* *$ & $* *$ & N.S & $* *$ \\
\hline
\end{tabular}

** Highly significant difference at $p \leq 0.01$; LSD least significant difference; AST aspartate aminotransferase ; ALT alanine aminotransferase; TRP traumatic reticuloperitonitis; TP traumatic pericarditis.

Means in the same column with different superscript letters are significantly different.

Tab. 3. Alteration in blood proteins in buffaloes suffering from Traumatic reticuloperitonitis and its sequelae (mean values \pm SE)

\begin{tabular}{|c|c|c|c|c|}
\hline \multicolumn{5}{|c|}{ Parameters } \\
\hline Groups & $\begin{array}{l}\text { Total proteins } \\
\text { (g/dl) }\end{array}$ & $\begin{array}{l}\text { Albumin } \\
\text { (g/dl) }\end{array}$ & $\begin{array}{l}\text { Globulins } \\
\text { (g/dl) }\end{array}$ & $\begin{array}{l}\text { Fibrinogen } \\
\text { (mg/dl) }\end{array}$ \\
\hline TRP & $9.25^{\mathrm{a}} \pm 0.07$ & $2.29^{b} \pm 0.08$ & $6.95^{\mathrm{a}} \pm 0.23$ & $484.4^{\mathrm{a}} \pm 4.20$ \\
\hline $\mathrm{TP}$ & $9.01^{\mathrm{a}} \pm 0.34$ & $2.35^{b} \pm 0.06$ & $6.65^{\mathrm{a}} \pm 0.30$ & $492.0^{\mathrm{a}} \pm 2.25$ \\
\hline $\begin{array}{l}\text { Healthy } \\
\text { buffaloes }\end{array}$ & $7.57^{b} \pm 0.14$ & $4.47^{\mathrm{a}} \pm 0.18$ & $3.09^{b} \pm 0.16$ & $231.6^{b} \pm 1.66$ \\
\hline $\mathrm{F}$ test & $* *$ & $* *$ & $* *$ & $* *$ \\
\hline
\end{tabular}

** Highly significant difference at $p \leq 0.01$; TRP traumatic reticuloperitonitis; TP traumatic pericarditis.

Means in the same column with different superscript letters are significantly different. 
diseases .So it can be used to differentiate between them and TP marker.

Acknowledgment. The author would like to thank Vet.Dr. Abdel El Menaem Ahmed Assistant lecturer of internal medicine department at the Faculty of Veterinary Medicine, Zagazig University in Egypt for their valuable help and support.

\section{REFERENCES}

1. Abd El-Aal A (2009). Advanced studies on traumatic reticuloperitonitis in cattle. Thesis, Zagazig University, Fac Vet Med (Internal Medicine).

2. Abd El-Aal A ,Floeck M ,El-Maghawry S, Baumgrtner W (2009). Clinical and ultrasonographic diferences between cattle and bufaloes with various sequelae of traumatic reticuloperitonitis. Veterinarni Medicina 54(9):399-406.

3. Benjamin M (1979). Fibrinogen. In : Outline of Veterinary Clinical Pathology. Iowa State University Press, Ames, USA.

4. Braun U, Goetz M (1994). Ultrasonography of the reticulum in cows. American J of Vet Research 55(3):325-332.

5. Braun U (2009). Traumatic pericarditis in cattle: clinical, radiographic and ultrasonographic findings. Vet J 182(2):176-186.

6. Braun U, Schweizer T, Pusterla N (2001). Echocardiography of the normal bovine heart: technique and ultrasonographic appearance. Veterinary Record 148(2):47-51.

7. Coles EH (1986). Veterinary Clinical Pathology. 4th ed, Philadelphia and London W.B. Saunders Company.

8. Collinson P, Boa FG (2001). Measurement of cardiac troponins. Ann Clin Biochem 38(5):423-449.

9. Cray C, Zaias J, Altman NH (2009). Acute phase response in animals: a review. Comparative Medicine 59(6):517-526.

10. Danjuma1 FA, Otolorin GR, Mshelbwala PP, Abubakar A (2014). Acute traumatic pericarditis in a 4-year-old Bunaji bull: a case report .Research 1:960.

11. Dirksen G, Gruender H, Stoeber M (1990). The Clinical Examination of Cattle (in German). Parey/Blackwell Publishing, Berlin.

12. Divers TJ, Peek SF (2007). Rebhun's disease of Dairy Cattle. 2nd ed. St Louis, Saunders-Elsevier, 130-199.

13. Douglas JW, Wardrop KJ (2010). Schalm's Veterinary Hematology. Philadelphia and Baltimore: Blackwell.

14. Doumas B, Baysa D, Carter R, Peters T, Schaffer R (1981). Determination of serum total proteins.Clin Chem 27(10):1642.

15. Drupt F (1974). Colorimetric method for determination of serum albumin. Pharm Bio Sci 7:999.

16. GOVS (2005). Technical veterinary report 2005. General Organization of Veterinary Service,Cairo,Egypt.
17. Gruys E, Obwolo MJ, Toussaint JM (1994) .Diagnostic significance of the major acute phase proteins in veterinary clinical Chemistry :a review. The Veterinary Bulletin 64:1009-1018.

18. Hajighahramani S, Ghane M (2010). Traumatic reticuloperitonitis in cattle of Khorramabad (center of Lorestan Provenience, west of Iran).Global Veterinaria 5(2):135-139.

19. Husdan H, Rapoport K (1968). Chemical determination of creatinine with deproteinization. Clin Chem 14:222238.

20. Jafarzadeh SR, Nowrouzian I, Khaki Z, Ghamsari SM, Adibhashemi F (2004). The sensitivities and specificities of total plasma protein and plasma fibrinogen for the diagnosis of traumatic reticuloperitonitis in cattle. Preventive Veterinary Medicine 65:1- 7.

21. Kahn CM, Line S (2010). The Merck Veterinary Manual, 10th ed. Whitehouse Station, N.J., Merck \& Co.

22. Kaneko JJ, Harvey JW, Bruss ML (2008). Clinical Biochemistry of Domestic Animals.6th ed .California,USA, Academic Press.

23. Kumar V, Abbas AK, Aster JC (2014). Robbins and Cotran Pathologic Basis of Disease (9th ed.). Philadelphia, Pa., Elsevier Saunders, 960, 1012.

24. Memeh C, Reid H, Edeko V, Ofoegbu R (1992). Postoperative hyperfibrinogenemia in gastrointestinal surgery. Clin Physiol Biochem 9:124-126.

25. Misk N, Semieka M, Ali S (2001). Varieties and sequellae of ingested foreign bodies in buffalo and cattle.Assiut Veterinary Medical Journal 46:250-273.

26. Mohamed T (2010). Clinicopathological and ultrasonographic findingsin 40 water buffaloes (Bubalus bubalis) with traumatic pericarditis.Veterinary Record 167(21):819824.

27. Putton C, Crouch S (1977). Determination of serum blood urea nitrogen." Anal Chem 49:464-469.

28. Radostits OM, Gay CC, Hinchcliff KW, Constable PD (2000). Veterinary Medicine.A textbook of the Diseases of Cattle, Horses, Sheep, Pigs and Goats, 10th ed. Baillier Tindall, London, Philadelphia, New York, 303-311.

29. Rebhun WC, Guard C, Richards CM (1995). Diseases of Dairy Cattle. Williams \& Wilkins, Philadelphia, 113-116.

30. Reitman S, Frankel S (1957). A colorimetric method for determination of serum glutamicoxaloacetic transaminase and serum glutamic pyruvic transaminase. Am J Clin Pathol, 25,56.

31. Saleh MA, Rateb HZ, Misk NA (2008) . Comparison of blood serum proteins in water buffaloes with traumatic reticuloperitonitis and sequellae. Res Vet Sci 85(2):208213. 
32. Tamhane A, Dunlop D (2000). Statistic and Data Analysis from Elementary to Intermediate. New Jersey, USA, Prentice Hall, Upper Saddle River.

33. Undhad V, Fefar T, Jivani BM, Gupta H, Ghodasara J, Joshi P (2012). Cardiac troponin: an emerging cardiac biomarker in animal health.Vet World 5(8):508-511.

34. Watts AS, Tulley WJ (2013). Case report: sequelae of traumatic reticuloperitonitis in a Friesian dairy cow. N Z Vet J 61(2):111-114.
35. Winder SJ, Walsh MP (1990). Smooth muscle calponin. Inhibition of actomyosin MgATPase and regulation by phosphorylation", J Biol Chem 265(17):10148- 10155.

36. Zethelius B, Johnston N (2006). Troponin I as a predictor of coronary heart disease and mortality in 70-yearold men: a community-based cohort study. Circulation 113(8): 1071-1078. 